\title{
Strategi Pengembangan Pendidikan untuk Meningkatkan Kualitas SDM di Madura Pasca Pembangunan Jembatan Suramadu
}

\author{
Muh Syarif ${ }^{1} \&$ Abdul Azis Jakfar ${ }^{2}$ \\ ${ }^{1}$ Program Studi Manajemen, Fakultas Ekonomi dan Bisnis \\ ${ }^{2}$ Program Studi Teknologi Industri Pertanian, Fakultas Pertanian \\ Universitas Trunojoyo Madura \\ E-mail: syarif98@gmail.com
}

Naskah diterima 10 November 2018, Revisi 23 Januari 2019, Terbit 20 April 2019

DOI: http://dx.doi.org/10.21107/pmt.v12i1.5175

\begin{abstract}
ABSTRAK
Penelitian ini mencoba mengkaji aspek Sumber Daya Manusia (SDM) dengan fokus bidang pendidikan. SDM dipahami sebagai salah satu faktor utama pendukung keberhasilan pembangunan di Madura. Berbagai permasalahan dan strategi pengembangan yang terkait dengan aspek SDM bidang pendidikan disampaikan dalam studi ini. Keberadaan lembaga pendidikan sangat diperlukan untuk menyiapkan sumber daya masyarakat. Lembaga pendidikan tidak hanya lembaga formal saja, namun juga lembaga non formal dan informal. Meningkatkan kualitas pendidikan dan menselaraskan kurikulum yang disampaikan dalam dunia pendidikan dengan kebutuhan industrialisasi di Madura harus segera dilakukan oleh lembaga pendidikan yang ada di Madura. Hal itu dilakukan agar SDM masyarakat Madura mampu memenuhi kebutuhan SDM industrialisasi yang ada di Madura. Pengembangan SDM bidang pendidikan di Madura umumnya seragam dengan wilayah lain tanpa melihat potensi sumberdaya lokal. Idealnya harus benar-benar dilihat bagaimana potensi dan permasalahan pendidikan di Madura sehingga dapat dilakukan strategi pengembangan dan indikasi programnya yang sesuai dengan kondisi yang ada dan nyata.
\end{abstract}

Kata Kunci: pendidikan, sumber daya manusia, industrialisasi, Madura

\section{PENDAHULUAN}

Eksistensi Jembatan Suramadu diharapkan menumbuh kembangkan perekonomian masyarakat Madura yang didukung oleh kesiapan masyarakat. Peningkatan perekonomian ini tentunya bukan untuk dinikmati oleh masyarakat di luar Pulau Madura, namun diprioritaskan untuk masyarakat Madura. Peningkatan perekonomian harus dimulai oleh kemampuan sumber daya masyarakat dalam memenuhi kebutuhan industri yang ada. Hal ini harus didukung dengan ketersediaan sarana dan prasarana untuk memenuhi permintaan industri. Keberadaan lembaga pendidikan sangat diperlukan untuk menyiapkan sumber daya masyarakat. Lembaga pendidikan tidak hanya lembaga formal saja, namun lembaga non formal dan informal juga diperlukan.

Saat ini lembaga formal, non formal dan informal di Madura sudah banyak.
Lembaga formal mulai dari SD (Sekolah Dasar), MI (Madrasah Ibtidaiyah), SMP (Sekolah Menengah Pertama), MTs (Madrasah Tsanawiyah), SMA (Sekolah Menengah Atas), MA (Madrasah Aliyah), maupun SMK (Sekolah Kejuruan). Selain itu, lembaga perguruan tinggi juga tersedia di setiap kabupaten di Pulau Madura. Selain itu, lembaga non formal yang berupa kursur-kursus juga tersedia (Rudi, 2012).

Selain itu, Pulau Madura terkenal dengan jumlah pondok pesantren yang banyak. Pondok pesantren ini juga menghasilkan sumberdaya masyarakat yang siap untuk bersaing dengan lulusan dari lembaga formal (Siradj, 2009; Wahjoetomo, 2010). Pondok pesantren menyelenggarakan juga pendidikan umum. Fenomena lembaga pendidikan formal dan non formal di Madura lebih banyak lembaga yang berbasis agama. Namun tidak dapat dipungkiri bahwa 
kualitas sumberdaya masyarakatnya tidak lebih baik pada saat harus bersaing di dunia industri. Hal ini dikarenakan kurikulum yang digunakan tidak sama. Selain itu, pendidikan tinggi di Pulau Madura lebih banyak berbasis pada bidang kesehatan dan pendidikan (Mastuhu, 2004). Hal ini ditunjukkan bahwa di setiap kabupaten mempunyai STKIP dan akademi kebidanan maupun akademi keperawatan.

Beranekaragamnya basis keilmuan dan ketimpangan kualitas pendidikan yang dihasilkan perlu dicarikan solusi. Solusi perlu dilakukan untuk memenuhi permintaan industri, sehingga sumberdaya masyarakat Madura dapat dimanfaatkan secara optimal. Oleh sebab itu, masyarakat Madura harus menyadari kemampuannya bersaing karena aktivitas dan pekerjaan dalam industrialisasi menuntut kecanggihan ilmu pengetahuan dan teknologi serta keterampilan (Skill). $\mathrm{Hal}$ itu hanya dapat diraih dengan belajar keras dan menuntut ilmu pengetahuan (berpendidikan) setinggi mungkin.

Pendidikan yang berkualitas dan mumpuni yang sesuai dengan permintaan pasar industrialisasi di Madura akan menyebabkan masyarakat Madura tidak hanya menjadi penonton kegiatan industrialisasi, tetapi masyarakat Madura akan mampu bersaing berdasarkan kemampuan dan pendidikan yang dapat diandalkan. Untuk itu, meningkatkan kualitas pendidikan dan menselaraskan kurikulum yang disampaikan dalam dunia pendidikan dengan kebutuhan industrialisasi di Madura harus segera dilakukan oleh lembaga pendidikan yang ada di Madura. Hal itu dilakukan agar SDM masyarakat Madura mampu memenuhi kebutuhan SDM industrialisasi yang ada di Madura.

Selain itu, tidak hanya sektor pendidikan perlu ditingkatkan. Potensi sumberdaya yang dimiliki oleh masingmasing kabupaten perlu digali dan manfaatkan secara optimal. Komoditas yang cukup menonjol di Madura seperti: ketela pohon, jagung, tembakau, garam, rumput laut dan jamu harus dikembangkan potensinya, sehingga eksistensi lembaga pelatihan dapat berperan melatih masyarakat untuk mengolahnya.

Rencana pengembangan SDM bidang pendidikan mencakup 2 (dua) aspek, yaitu: aspek spasial dan aspek non spasial. Aspek spasial menyangkut hal-hal yang terkait dengan perencanaan tata ruang wilayah Madura, termasuk diantaranya perencanaan kawasan Madura sebagai kawasan industrialisasi, serta keterkaitan antar kawasan dan keterhubungan atau aksesibilitasnya. Aspek non spasial, khususnya yang terkait dengan pengembangan sumber daya manusia dan kelembagaan, mekanisme kerjasama antar lembaga dan hal-hal lainnya, termasuk keterkaitan antar sektor dalam mendukung pengembangan bidang pendidikan.

Pengembangan SDM bidang pendidikan di Madura umumnya seragam dengan wilayah lain tanpa melihat potensi sumberdaya lokal. Idealnya harus benarbenar dilihat bagaimana potensi dan permasalahan pendidikan di Madura sehingga dapat dilakukan strategi pengembangan dan indikasi programnya yang sesuai dengan kondisi yang ada dan nyata.

Madura memiliki potensi pertanian, perikanan laut, industri kecil, pertambangan, dan lainnya yang cukup layak untuk dikembangkan. Sayang sekali, jika peluang potensi tersebut tidak dikelola dan dikembangkan secara baik justru akan diisi oleh SDM dari wilayah lain. Potensi wilayah yang dimiliki suatu daerah merupakan modal dasar pelaksanaan pembangunan daerah pada era otonomi. Upaya dilakukan melalui kebijakan pengembangan potensi berupa penyediaan sarana dan prasarana pembangunan termasuk diantaranya penyediaan dan peningkatan sumber daya manusia (SDM).

Kondisi pendidikan di Madura saat ini masih perlu dibenahi, baik kualitas, kuantitas maupun relevansinya. Tujuan dari kegiatan ini adalah menganalisis tentang pengembangan SDM sesuai potensi di Madura. Potensi sumber daya alam cukup besar, dan memiliki jumlah penduduk yang terus meningkat merupakan potensi lokal yang harus dikelola. 
Seiring dengan kondisi tersebut pemerintah perlu melakukan inisiasi kebijakan pengembangan potensi wilayah yang sinergis dengan peningkatan mutu SDM, sehingga masyarakat dapat terkonsentrasi pada aktivitas pengolahan potensi sumber daya alam yang ada. Diharapkan bahwa dari implementasi pembangunan dan peningkatan sumber daya manusia dapat sesuai dengan potensi kewilayahan.

Penelitian ini bertujuan untuk : (1) mengetahui kondisi eksisting sarana dan prasarana pendukung pengembangan SDM masyarakat Madura peluang dan kendala pengembangan SDM masyarakat Madura; (2) merumuskan program dan prioritas pengembangan SDM masyarakat Madura berdasarkan kondisi, fungsi, dan potensi.

\section{METODOLOGI \\ Pengumpulan Data}

Pengumpulan data sekunder dilakukan dengan mengumpulkan data berbagai sumber dan pihak terkait (Dinas Pendidikan dan Kebudayaan, Kantor Kemenag, Bappeda serta instansi terkait lainnya), internet, jurnal, hasil penelitian, majalah, koran dan sebagainya. Selain itu, data diperoleh dari hasil kajian terhadap peraturan-peraturan dan kebijakan terkait bidang pendidikan. Sementara itu, pengumpulan data primer dilakukan dengan observasi langsung di lokasi kegiatan pada saat pelaksanaan kegiatan melalui kegiatan observasi, dan diskusi (FGD) dengan stakeholder.

\section{Pelaksanaan FGD}

Pelaksanaan kegiatan FGD mengemban agenda untuk melakukan serap aspirasi, utamanya untuk menyusun rencana induk pengembangan SDM Madura bidang pendidikan. Peserta FGD adalah multi-stakeholder bidang pendidikan se Madura,, meliputi: pimpinan perguruan tinggi, pendidikan formal, pendidikan informal, pendidikan non formal, Dinas Pendidikan, Kemenag di tingkat Kabupaten, LSM dan media massa.

\section{Analisa Data}

Berisi aktifitas untuk menganalisa data primer dan sekunder yang telah dikumpulkan kemudian ditabulasi dan dianalisis secara kualitatif dan deskriptif yang kemudian disajikan dalam bentuk tabel untuk nantinya dinarasikan.

\section{HASIL PEMBAHASAN}

Arah pengembangan kawasan industrialisasi di Madura yaitu industri yang berbasis potensi dan industri perluasan dari daerah lain (Surabaya, Gresik, Sidoarjo dan daerah lain). Industri yang berbasis potensi dikembangkan berdasarkan bahan baku yang terdapat di Madura serta menggunakan pertimbangan sektor-sektor yang ada pada PDRB.

Berdasarkan potensi yang terdapat di Madura terdapat peluang investasi dari komoditi unggulan di Madura, yaitu: sektor pertanian, perkebunan, perikanan dan kelautan, peternakan, pertambangan, dan pariwisata. Pada tahun 2020 sektor-sektor potensial tersebut diperkirakan akan mampu menyerap tenaga kerja sebanyak 10.773 tenaga kerja.

Disamping industrialisasi yang berbasis komoditi unggulan di Madura, maka diharapkan akan muncul industri ekspansi dari daerah-daerah lain, seperti: Surabaya, Gresik, Sidoarjo, Pasuruan dan daerah yang lain. Industri yang mungkin masuk ke Madura di antaranya: Industri IT, Industri Telekomunikasi, Industri Elektronik, Industri Kreatif, Industri Otomotif, Industri Kimia, Industri Logam Dasar dan lain-lain. Seiring dengan pengembangan kawasan industrialisasi di Madura, maka perlu dipersiapkan SDM Madura. Hal itu dilakukan agar orang Madura tidak menjadi penonton di wilayahnya sendiri. Pengembangan SDM Madura tidak terlepas dari tiga hal yaitu indek kesehatan, pendidikan dan daya beli yang disebut dengn IPM (Indeks Pembangunan Manusia).

\section{Skenario Pengembangan SDM Madura} Bidang Pendidikan

Pengembangan pendidikan di Indonesia menggunakan empat strategi dasar, yakni: (1) pemerataan kesempatan untuk memperoleh pendidikan; relevansi; (3) peningkatan kualitas dan (4) 
efisiensi. Secara umum strategi itu dapat dibagi menjadi dua dimensi, yakni: peningkatan mutu dan pemerataan pendidikan. Pembangunan peningkatan mutu diharapkan dapat meningkatkan efisiensi, efektivitas dan produktivitas pendidikan. Dimensi pemerataan pendidikan diharapkan dapat memberikan kesempatan yang sama dalam memperoleh pendidikan bagi semua usia sekolah.

Salah satu upaya pemerataan pendidikan di Indonesia adalah program Wajib Belajar (Wajar) 9 tahun yakni Sekolah Dasar (SD) 6 tahun dan Sekolah Lanjutan Tingkat Pertama (SLTP) selama 3 tahun. Kebijakan ini disebut sebagai upaya menerapkan pendidikan minimal yang harus dimiliki oleh seluruh bangsa Indonesia yang erat kaitannya dengan gerakan melek hurup dan masyarakat belajar.

Skenario pembangunan pendidikan di Madura harus berbasis manusia. Alasannya, banyaknya krisis moral yang terjadi akibat dari kesalahan dunia pendidikan yang lebih menekankan aspek pengetahuan dan melupakan sikap, nilai, dan perilaku. Pendidikan di sekolah tersampaikan dalam penyajian yang hampa makna. Misi setiap mata pelajaran terselewengkan menjadi penerusan materi (content transmission). Guru hanya menjadi pemberi informasi tentang mata pelajaran di kelas yang decontextualized. Siswa menjadi "tong sampah" materi yang ditumpahkan guru. Akibatnya, perkembangan otak siswa tidak maksimal dan miskin ide baru. Lembaga pendidikan di Madura harus bisa bersifat contextualized agar pendidikan bisa memberi manfaat langsung kepada peningkatan kualitas masyarakat dalam kehidupan di daerah setempat/lokal.

Pendidikan sebelumnya yang banyak dijalankan bersifat sentralistik berdampak pada kebijakan Pusat seragam untuk seluruh wilayah, termasuk lokal Madura. Padahal kebutuhan dan karakteristik daerah sangat beragam. Akibatnya pendidikan pun menghasilkan lulusan sentralistik yang tidak dapat secara langsung dimanfaatkan oleh daerah. Kompetensi lulusan SD, SMP, SMA tidak dapat mengelola potensi yang ada di daerah. Walhasil, berbondong-bondong usia SD-SMP-SMA ke kota untuk bekerja secara apa adanya. Desa/daerah kosong ditinggalkan penghuni produktifnya. Desa kehilangan generasi penerus pembangun daerah. Pembangunan di daerah (desa, kecamatan, kabupaten) mandeg atau berjalan sangat lambat. Dalam hal ini pendidikan menjadi kemubaziran karena tidak berwawasan pembangunan lokal (daerah).

Strategi pengembangan pendidikan di Madura harus merujuk pada Kurikulum berbasis potensi daerah. UU No: 20 tahun 2003 tentang SISDIKNAS dan PP No: 19 tahun 2005 tentang Standar Nasional Pendidikan telah memberikan banyak ruang bagi lembaga pendidikan untuk membuat dan mengelola kurikulumnya sesuai dengan potensi dan kompentensi wilayah/lingkungan yang dimilikinya. Kesempatan ini hendaknya dapat dimanfaatkan oleh masing sekolah atau pihak pemerintah daerah setempat untuk menciptakan sebuah lembaga pendidikan yang lebih terarah, cakap dan terampil.

Pendidikan yang mampu meningkatkan mutu SDM untuk mengelola sumberdaya atau potensi daerah adalah pendidikan yang dikembangkan dengan kurikulum berbasis potensi daerah. Kurikulum yang bersifat nasional merupakan kerangka, yang menjadi daging dan kulit adalah kurikulum yang dikembangkan oleh daerah

Fakta perihal belum sesuainya kurikulum pendidikan yang mampu mengelola potensi daerah, banyak ditemui pada setiap daerah. Secara faktual, hal itu terlihat dari belum adanya manfaat nyata (real benefit) bagi daerah tempat sekolah itu berada, khususnya didaerah-daerah yang memiliki banyak potensi alam yang produktif. Padahal, Madura memiliki berbagai ragam budaya dan kekayaan alam yang bisa dikembangkan dan dikelola melalui kurikulum pendidikan sekolah (kurikulum lokal). Kurikulum sekolah di daerah pesisir, misalnya, sepatutnya tidak disamakan dengan kurikulum sekolah di daerah pertanian. Seyogianya, kurikulum di daerah pesisir mengandung aspek / materi ajar yang terkait dengan kehidupan nelayan : 
pembuatan perahu, alat tangkap, pengawetan ikan, pengembangbiakan ikan laut, dan wirausaha ikan laut.

Dalam melakukan pengembangan kurikulum berbasis potensi daerah di Madura hendaknya memiliki beberapa landasan pengembangan kurikulum, kemudian landasan tersebut dipadukan secara rasional dan bersenyawa. Adapun landasan tersebut minimal terdiri atas landasan ideal dan yuridis.

1. Landasan Ideal adalah landasan pokok yang berfungsi sebagai dasar dalam pengembangan kurikulum berbasis potensi daerah. Landasan ini terdiri dari beberapa sub sistem serta memiliki sistimatika berfikir sebagai berikut : Kurikulum nasional sebagai kerangka dasar, potensi daerah sebagai sumber belajar dan ilmu sebagai metodologi, kemudian melahirkan curriculum content, hidden curriculum, bahan ajar, standar kelulusan, standar evaluasi, dll, dengan memiliki sasaran target : membentuk peserta didik sebagai sentra pembangunan daerah yang memiliki ilmu dan berkarya unggul.

2. Landasan Yuridis adalah landasan hukum yang berfungsi sebagai rujukan standar minimal dalam pelaksanaan kurikulum. Landasan tersebut, antara lain: UU RI No. 20 tahun 2003 tentang Sisdiknas, PP, Kepres, Kepmen dan KTSP.

Strategi secara umum yang disepakati untuk mengatasi persoalan pendidikan di Madura, meliputi:

\section{Strategi Pengembangan Pendidikan Tingqi}

1. Pola pembelajaran harus menekankan pada aspek kognitif dan afektif (pembentukan karakter). Pelaksanaan proses pembelajaran disamping meningkatkan keterampilan/Skill peserta didik juga dilakukan dengan proses pembelajaran yang melatih atas dasar kejujuran, disiplin dan rasa tanggung jawab.

2. Penyempurnaan kurikulum (materi yang esensial dan mendukung muatan lokal)

3. Menerapkan kurikulum berbasis entrepreneurship yang sinergi atas pendidikan dasar, menengah, dan tinggi untuk mencetak SDM Madura yang mandiri.

4. Memberikan kesadaran bagi peserta didik pentingnya Skill (hard Skill dan soft skill) dalam menghadapi era yang akan datang sehingga kuliah bukan hanya mengejar ijazah.

5. Pengembangan sarana prasarana yang menciptakan lingkungan yang nyaman untuk belajar.

6. Pengembangan kemampuan tenaga pendidikan melalui ijin belajar, tugas belajar, pelatihan, seminar, maupun kegiatan lain.

7. Meningkatkan jumlah tenaga pengajar sesuai dengan rasio mahasiswa serta rekrutmen yang sesuai dengan bidang keahlian.

8. Meningkatkan kesejahtreraan tenaga pengajar agar tenaga mengajar dapat melaksanakan tugasnya secara profesional.

9. Dukungan dari pemerintah untuk pemberian beasiswa kepada masiswa yang kurang mampu dan berprestasi.

\section{Strategi Pengembangan Pendidikan Formal}

1. Program pengembangan SDM harus seimbang dengan program-program pembangunan yang lain.

2. Optimalisasi Program Kejuruan demi terwujudnya kreativitas anak muda yang ada di Madura lebih-lebih untuk mempersiapkan industrialisasi yang akan berkembang di Madura maka optimalisasi program kejuruan ini sangat dibutuhkan, sehingga nanti bisa mengembangkan kreativitas, keterampilan dan keahlian dalam bidang tertentu

3. Pembenahan aspek sosial budaya. Dengan adanya perkembangan teknologi maka tidak heran kalau terkadang siswa malah cendrung lebih mengikuti trend sehingga tidak lagi menghiraukan prestasi dalam bidang pendidikannya, maka diperlukan pengawasan dari orang tua serta bimbingan dari guru agar aspek social dan budaya di Madura bisa lebih baik

4. Reward untuk anak yang berprestasi. Penghargaan/Reward terhadap siswa yang berprestasi ini perlu ditingkan lagi 
di Madura, sehingga siswa-siswa yang lain bisa termotivasi untuk belajar lebih giat lagi, namun yang perlu diperhatikan secara serius adalah siswa yang pintar tapi berasal dari kalangan orang yang tidak mampu,sehingga nanti tidak terhambat dengan masalah biaya dan bisa melanjutkan sekolah ke jenjang yang lebih tinggi.

5. Penataran terhadap guru Tsanawiyah dan MI perlu ditingkatkan. Penataran ini bertujuan agar kualitas guru di Tsanawiyah dan MI bisa setara dengan sekolah-sekolah formal lainnya seperti SMP dan SD, sehingga tidak ada perbedaan yang sangat jauh dalam hal prestasi ungtuk siswanya kareana masing-masing guru di tiap sekolah mempunyai kemampuan yang sama.

6. Tingkatkan Mutu Guru. Mutu guru sangat berpengaruh terhadap prestasi siswa, karena keberhasilan proses belajar mengajar yang paling utama adalah bagaimana seorang guru bisa memberi pemahaman kepada siswanya dalam menempuh mata pelajaran.

7. Transparansi Dana Operasional Sekolah, seperti: BOS. Perlu dana yang transparansi dari dana operasional sekolah karena ada sebagian lembaga-lembaga pendidikan yang tidak transparansi masalah itu, sehingga proses belajar-mengajar sedikit terhambat.

8. Program Khusus tentang pembebasan tanah, khususnya untuk pendidikan dan pembangunan.

\section{Strategi Pengembangan Pendidikan} Non Formal

1. Pendekatan kemanusiaan (humanistic approach), masyarakat dipandang sebagai subjek pembangunan. Masyarakat diakui memiliki potensi untuk berkembang dan sedemikian rupa ditumbuhkan agar mampu membangun dirinya.

2. Pendekatan partisipatif (participatory approach), mengandung arti, bahwa masyarakat, lembaga-lembaga terkait, dan atau komunitas dilibatkan dalam pengelolaan dan pelaksanaan pembangunan masyarakat.
3. Pendekatan kolaboratif (collaborative approach), dalam pembangunan masyarakat perlu adanya kerjasama dengan pihak lain (terintegrasi) dan terkoordinasi dan sinergi.

4. Pendekatan yang berkelanjutan (continuation approach) untuk itulah pembinaan kader yang berasal dari masyarakat adalah hal yang paling pokok.

5. Pendekatan budaya (cultural approach) penghargaan budaya dan kebiasaan, adat istiadat yang tumbuh di tengahtengah masyarakat dalam pembangunan masyarakat adalah hal yang perlu diperhatikan.

\section{KESIMPULAN}

Skenario pengembangan SDM Madura ditentukan oleh kolaborasi pendidikan umum (kurikulum Diknas) dan agama (kurikulum Kemenag), pendidikan pesantren dan pendidikan non formal. Pemikiran manajemen pendidikan terpadu akan banyak ditentukan oleh tujuan dan arah keterpaduan, yang menyatakan bahwa arah pendidikan saat ini adalah dalam pembinaan IPTEK, IMTAQ, dan Skill fungsional. Keterpaduan akan ditekankan dalam menata manajemen dan implementasinya yang untuk saat ini harus dimiliki oleh lembaga pendidikan umum, agama, non formal dan pesantren dengan strategi pengembangan pendidikan yang telah dirumuskan.

\section{DAFTAR PUSTAKA}

Hana, R. 2012. Perubahan-perubahan Pendidikan di Pesantren Tradisional (Salafi). Jurnal Tadris. Vol 7 No 2.

Mastuhu. 2004. Dinamika Pesantren. Jakarta: INIS

Siradj, S.A. 2009. Pesantren Masa Depan Wacana Pemberdayaan dan Transformasi Pesantren. Bandung: Pustaka Hidayah.

Wahjoetomo. 2010. Perguruan Tinggi Pesantren, Pendidikan Alternatif Masa Depan. Jakarta: Gema Insani Press 
Syarif, M \& Jakfar, A.A Strategi Pengembangan Pendidikan 23 